\title{
32. 透析液不要型装着式人工腎臓の試作
}

\section{はじめに}

かねてより，わ礼わ机は携行式小型人工腎臟 装置の開発のため, 透析液不要型人工腎臟に興 味をいだいてきた。

Hemofiltration の知識から梳, 週 3 回の操 作ごとに約 $20 l$ の希釈液が必要であり，これ走 連日行うと寸れば，抢上そ10l/dayの希瀵液が 必要であると思われる。そこで，この $10 l$ の希 䣋液を経口的に摂取して, 血液限外滤過のみを 行うことで, 満足な溶質除去が行えないかとい うのが, この研究の始まりである。このような ことが可能であれば， $10 l$ の水と十分な電解質 を経口的に補給し，血液限外滤過装置のみを装 着使用することで, 血液浄化が可能なはずであ る. この目的から, 新しい方式の装着型装置 JAK-2 を試作したので報告する.

\section{方法および材料}

写真 1 は今回試作した JAK-2 の外観であ る. 本方法は経口摂取によって水や電解質を補 給し，血液限外滤過のみを行らため，透析液お よび Hemofiltration 時における無菌的な希釈 液なども不要となる。したがって装置として は, Pump, Hemofilter, 体外回路抢よび若干 の Monitor 類があればよく，相当な小型化が 可能である. 本体の寸法は, たて, よこ, 高さ がそれぞれ $5.5 \mathrm{~cm}, 11 \mathrm{~cm} ， 22 \mathrm{~cm}$ であり，重 量は電源なども全て含めて，わずか $2.1 \mathrm{~kg}$ と小 型軽量になっている。このため, 専用の Jacket を着用すれば，随時携行㧍よび装着が可能であ

* 東京女子医科大学人工腎臓センター

** 川澄化学工業
小作保䬺* 阿岸鉄三* 山下賀正 ${ }^{*}$ 江良和䧸*太田和夫*安部道夫炏 小野俊弆**

る.

写真 2蜾本機に用いた Pump 駆動用 Motor およびギヤへッドである。こ机は $9 \mathrm{~V}$ 用の小珰 Servo motorで, 出力は11.5Wである. 回転效 は無負荡侍で $5,800 \mathrm{rpm}$ が得られるが，これを ギヤへッドで約90分の 1 にShiftして実際の沽 力軸の回転数法 0 から 60rpm にコントロール さ机る。こ礼によって装挚型人工腎臟用血济

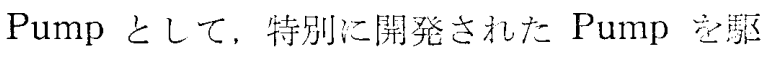
動させる。このPump は, 大口と出口を, 并 れぞれ交互に開しなが閉し血液を送る方式のb

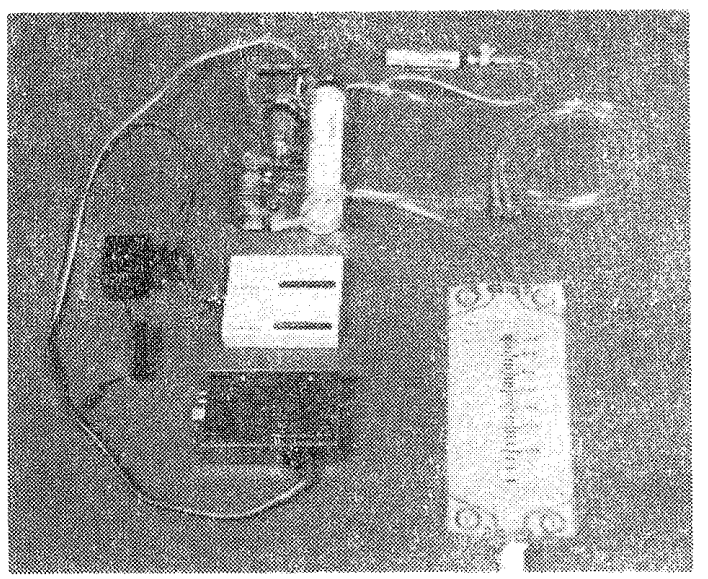

写真 1

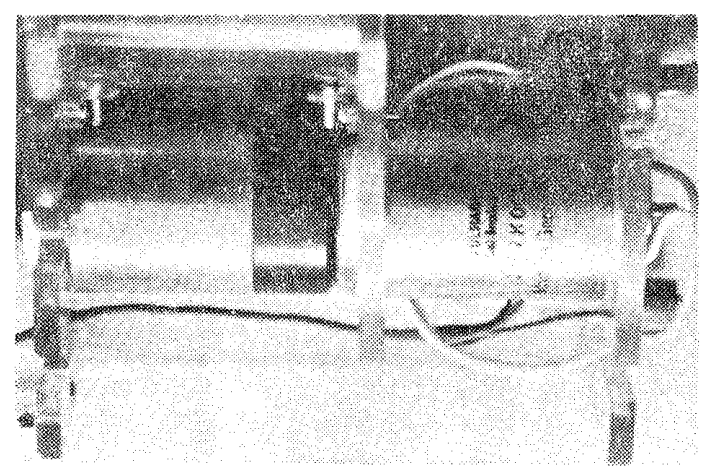

写真 2 


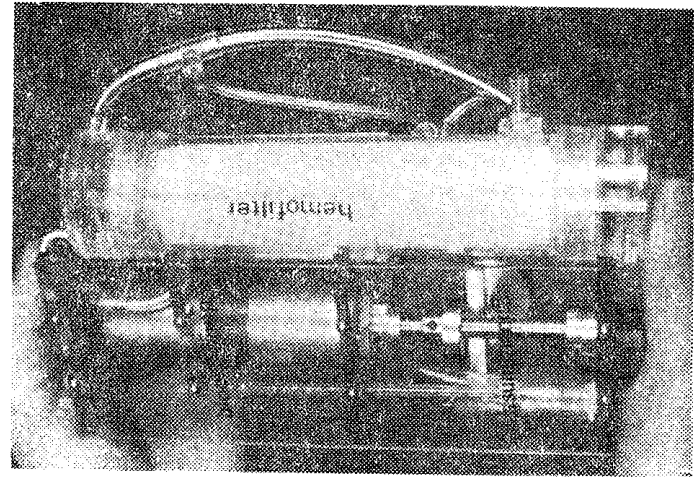

写真 3

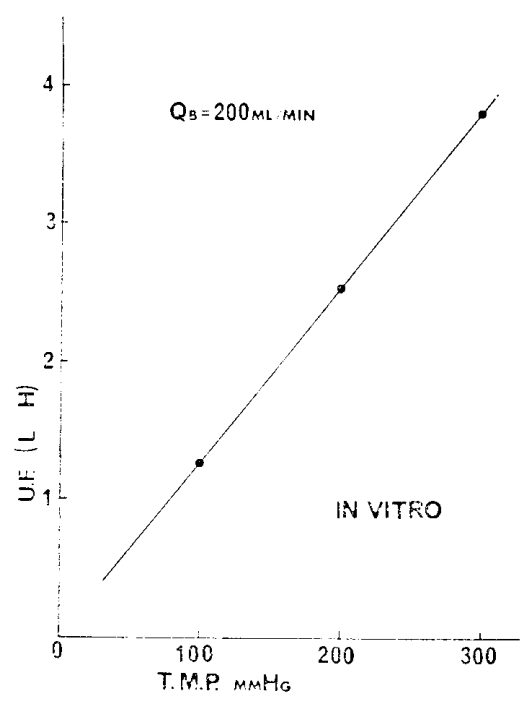

図 1

のだ，劼のの゙た Servo motor と Cam shaft つ解合さで正確な動作をする。これ机よって血

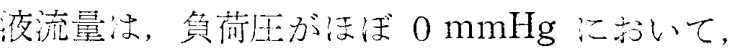
最大 $300 \mathrm{ml} / \mathrm{min}$. 志で得ることができる。 ま た, このPump 蛹脈压 $300 \mathrm{mmHg}$ 立で:十 分に機能を発揮できる。

写真 3 に今回用いた Hemofilter 总示した。 これは E.V.A. 膜使用のクラレ繁 High flux type Hollow fiber である。この Hemofilter の主な仕㥞は内径 $335 \%$, 躁厚 $50 \%$, 中空糸数 5,000 本, 漟過面積 $0.7 \mathrm{~m}^{2}$, 外径寸法纱直径 45 $\mathrm{mm}$ ，長さ200mmである。

本 Hemofilter の除水性能学図 1 亿示した。 除水率虫 $200 \mathrm{mmHg}$ 亿扮いて約 $12.5 \mathrm{ml} / \mathrm{mm}$ Hg. h である。こ机々り約 $10 l$ の水分㧍よび

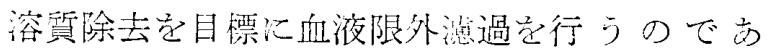
る。澺液况，プラスチック製のバッグに集的， 時間的涻てる上うにした。こ礼ら体外回路仗 血液 Pump 系含的て完全ディスポーザブル

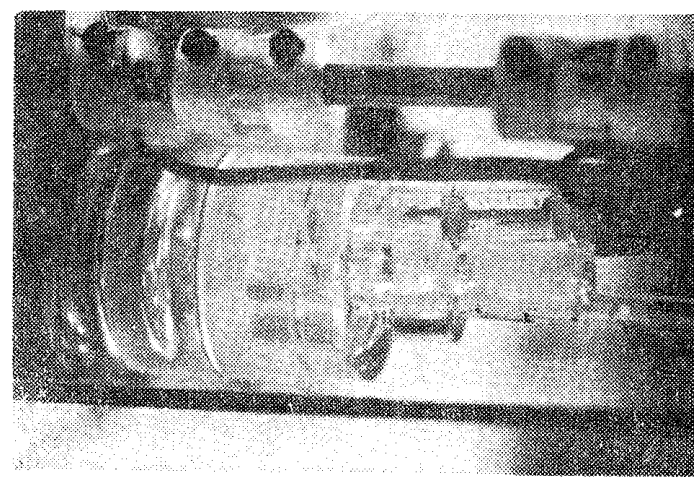

写真 4

化となって晾り，本装置の簡素化，小型化比つ ながっている。

写真4は湎過压 Monitor である。これによ って $200 \mathrm{mmHg}$ まで計测が可能である。これ は水銀柱学利用しているもので, 動作は血庄計 と同様である。何んら交の理由によって，200 $\mathrm{mmHg}$ 学超える王力が加わると電気回路が成 立し，警燮が発せられ，Pump は停止する。 この警報は Leak monitor の警報と其通になっ ている.

電源としては、ニッケル・カドニウム・ドラ イ・バッテリを 8 本㨁列接続して, 直流 $9.6 \mathrm{~V}$ を用いた。これてょって本装置は約 2 時闒の連 続動作が可能で, 容量不足になるとパイロット ランプが点減をし始的る。この状態加ら10分以 内にスパアのバッテリと交換する。本バッテリ は，300回の充電が可能で，一般には $8 \sim 10$ 洔

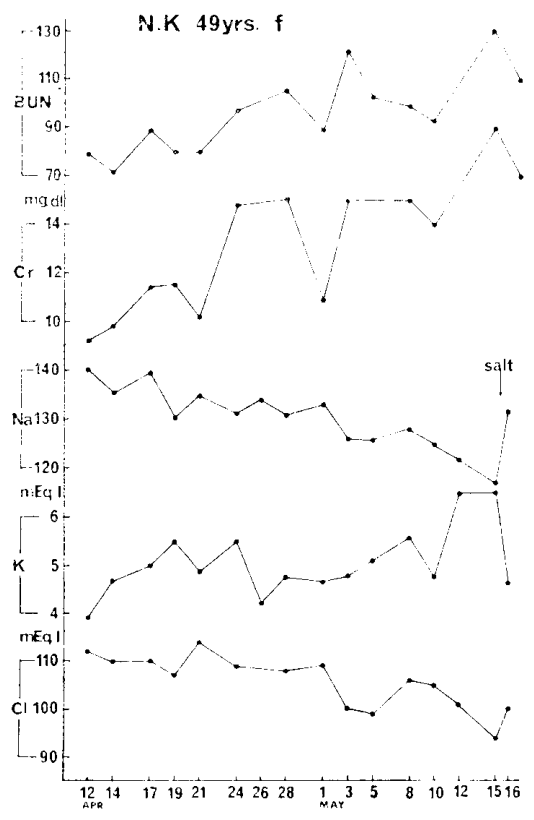

図 2 
医器学 Vol. 48, Suppl. (1978)

間で完全充電となる。

コントロール部には, 電源スイッチ, モータ スピードコントローラ, フローメータ, リーク モニタ, バッテリ消耗チェック機構, 各パイロ ットランプなどが組み込まれており，電子回路 は全て半導体である。

図 2 は，本方法により週 3 回の血液限外滤過 のみを施行している，一臨床例であるが，図の ごとく尿素窒素, クレアチニンについては短期 間であれば十分施行可能であり，電解質につい ても，ほぼ満足できる範囲内にあり，本方法の
将来性が期待される.

\section{結 語}

本方法によって透析液は不要となり，装置の 小型化が実現できる。また施行中に単独での移 動も自由で, 従来の透析に比較して束縛感など も十分緩和される，したがって，透析施設のな いところへの短期間の旅行などにも十分利用す ることができ，本方法および装置の有效性が期 待できる。しかし，現時点では $\mathrm{pH}$ 等の調整に 若干問題点があり，今後更に検討を重稀てゆく 必要があると思われる。 